\title{
Rabies virus spread in central and north-eastern regions of Ukraine
}

\author{
DHANNA O. OMELCHENKO ${ }^{1}$, DNATALIA O. AVRAMENKO ${ }^{1}$, SIERGIEJ M. KULYNYCH ${ }^{1}$, \\ ANATOLIJ A. POLISHCHUK ${ }^{1}$, Ф MAKSYM O. PETRENKO ${ }^{1}$, ๑PAWEŁ S. SYSA ${ }^{2}$, \\ ๑) GRZEGORZ J. WOŹNIAKOWSKI ${ }^{3}$
}

\author{
${ }_{1}^{1}$ Poltava State Agrarian Academy in Poltava, Skovorody St, 1/3, Poltava, Poltava Oblast, 36003 Ukraine \\ ${ }^{2}$ Department of Basic and Preclinical Sciences, ${ }^{3}$ Department of Diagnosis and Clinical Sciences, \\ Institute of Veterinary Medicine, Faculty of Biological and Veterinary Sciences, \\ Nicolaus Copernicus University in Toruń, Lwowska 1, 87-100 Toruń, Poland
}

Omelchenko H. O., Avramenko N. O., Kulynych S. M., Polishchuk A. A., Petrenko M. O., Sysa P. S., Woźniakowski G. J.

Rabies virus spread in central and north-eastern regions of Ukraine

\section{Summary}

Annually, 30,000-45,000 cases of rabies in animals and humans are reported worldwide. The aim of the study was to present data on the incidence of rabies among humans and animals in central and north-eastern regions of Ukraine (Poltava and Sumy) between the years 2007 and 2020. The statistical data were obtained from the anti-epizootic measures division at the Department of Food Safety and Veterinary Medicine of the State Food and Consumer Service in the Poltava and Sumy regions of Ukraine. Between 2012 and 2020, the largest number of bite cases in the Poltava region were recorded in 2012 (4,234 cases), and the lowest in 2018 (1,951 cases). The vast majority of bites were caused by dogs and cats that had an owner. During the successive years, the number of rabies cases increased. Between 2017 and 2019, over 50\% of rabies cases in the Sumy region occurred in domestic animals. Although combating rabies among dogs through vaccination, as well as extermination of homeless animals, may reduce the incidence of rabies in humans, rabies in dogs is still not uncommon in the Poltava and Sumy regions of Ukraine. Moreover, rabid dogs in these two regions still account for over $90 \%$ of rabies cases and $99 \%$ of deaths due to rabies among humans. The red fox was the leader in the incidence of rabies among wild animals between 2009 and 2019. In the Poltava region, the highest number of rabies cases occurred in 2017 (10 cases), whereas in the Sumy region the peak if infections was observed in 2010 (42 cases). Rabies in animals tended to decrease due to the oral immunization of free-ranging animals. It is difficult, however, to assess the overall global situation of rabies using data solely on human mortality. Rabies is not a purely human disease. It is rather a disease that occurs in wild and domestic animals, from which it may be transferred to humans. Therefore, a more accurate prediction of its impact should include an assessment of its prevalence in animal populations, especially pets, and the costs associated with preventing the spread of rabies from animals to humans. Effective measures for prevention and eradication of rabies, as well as better knowledge, are crucial to check further spread of the disease. Obligatory preventive measures should include vaccination of pets and oral immunization of red foxes.

Keywords: epizootic situation, rabies. spread, humans, animals

Rabies is an infectious, notifiable viral disease of animals and humans that causes severe clinical signs, including polyencephalomyelitis, leading to death of infected individuals $(12,21,22,41)$. Annually, 30-45 thousand cases in animals and 35-50 thousand cases in humans are notified worldwide. The rabies virus (RV) belongs to the Lyssavirus genus of the Rhabdoviridae family and in $99 \%$ of cases is transmitted by dogs. In recent decades, there has been a rapid increase in rabies incidence in the cat population due to the lack of proper vaccination among domestic and stray animals. Under such conditions, the virus presents a potential a threat to humans because of the increasing number of bites by infected animals. In many countries of Asia and Africa, stray dogs are a major source of infection for humans. Illegal import of animals poses a high risk of 
rabies transfer. Illegally imported dogs infected with RV were reported in France (2012 and 2015), Spain (2013), and the Netherlands (2013). The recurrence of rabies in northern Italy between 2008 and 2011 or in Greece between 2012 and 2013 demonstrates the importance of maintaining a high level of awareness. Data on rabies surveillance in animals in Europe are available online from the WHO Center for Rabies Monitoring and Research and from the ECDC/EFSA Joint Report on Trends and Sources of Zoonoses, Zoonotic Agents and Food-borne Outbreaks (31, 35, 42 ). In Europe, rabies has been historically reported in dogs, and the disease has been gradually eradicated at the turn of the twentieth century in most European countries through measures among free-ranging dogs (extermination, motion restrictions). Since the 1940s, the virus has adapted to the red fox (Vulpes vulpes) and has been spreading from Russian Federation to the west and south of Europe at the rate of $20-60 \mathrm{~km}$ per year. Rabies is a notifiable disease in most European countries $(33,36,40)$. Every year, rabies causes approximately 59,000 deaths worldwide. Although controlling rabies in dogs through animal vaccination programs may reduce the incidence of human rabies, canine rabies remains widespread in many countries, and exposure to rabies in dogs still accounts for over $90 \%$ of rabies cases in humans and $99 \%$ of rabies deaths in the world. Because rabies vaccines have been available for more than 100 years, most deaths from rabies occur in countries with insufficient health care resources and limited access to preventive treatment. These countries also lack diagnostic facilities and have almost no rabies surveillance.

Active foci of natural rabies exist throughout the whole territory of Ukraine, most of them having been identified in the Chernihiv, Sumy, Poltava, Kharkiv, Kirovohrad, Khmelnytsky, and Luhansk regions (19, $28,37)$. About 110,000 persons seek medical assistance because of animal bites every year, almost 20,000 of which are vaccinated against rabies. An analysis of the rabies epizootic situation in Ukraine between 1999 and 2018 showed that the disease was diagnosed in 10 species of domestic animals and in 18 free-ranging animal species. Annually, up to 20,000-23,000 persons were prescribed rabies vaccinations, and more than $60 \%$ of them had to be treated according to vital indications. It has been found that, in recent decades, cats have become a source of hydrophobia in humans in $39.6 \%$ of cases, which is also the highest index compared to other animals. The number of persons bitten or salivated on by animals suspected of rabies ranged from 879 (2016) to 3983 (2007). The large number of bites in 2007 is not surprising, because rabies among animals reached its peak at that time. A total of 63,753 (2014)-110,202 (2003) people applied for antirabic treatment, whereas $14.8 \%(14,149$ persons) were vaccinated in 2006 and $23.3 \%$ (16,131 persons) in 2017. Unfortunately, during that period, 58 people died. The above epidemic situation is alarming, as it requires government intervention in the implementation of preventive and educational measures.

In Ukraine, the epizootic situation of rabies has been very difficult in recent years. The country seems to be an epicenter of rabies in Europe (13, 15-17, 24). Despite a decrease in rabies outbreaks (by 319 cases, compared with 2011), the incidence rate remains high. A total of 1262 rabies-affected localities have been recorded since the beginning of the 2021 .

In the Poltava region, cases of rabies were observed more frequently in February 2021 among cats, dogs, foxes, and raccoon dogs (37). In the Chernihiv region, the percentages of cases recorded in 2016 and 2017 were, respectively, $42.3 \%$ and $44.4 \%$ in cats, $22.5 \%$ and $19.4 \%$ in dogs, and $21.6 \%$ and $16.7 \%$ in foxes (8). Out of the 9 regions in northern and western Ukraine, Khmelnytsky and Zhytomyr regions have the most severe epizootic situation with regards to animal rabies. The two regions alone account for $52 \%$ of all rabies cases recorded in these 9 regions $(1,5)$. Between 2014 and 2016, 57 localities and areas in the Lviv region were recorded as being affected by animal rabies. The majority among RV-infected animals were foxes $(\mathrm{n}=36,63.16 \%)$, followed by dogs $(\mathrm{n}=11,19.30 \%)$, cats $(\mathrm{n}=9,15.79 \%)$, and ferrets $(\mathrm{n}=1,1.75 \%)(14)$.

In the Russian Federation, rabies among humans is recorded sporadically: the number of notifications does not exceed 6 persons per year. Most of RV-infected people were bitten by dogs or cats $(59.9 \%)$. Bites by wild animals caused $35 \%$ of human rabies cases. New features of the northward and eastward spread of rabies in Russia include a decreasing role of foxes and an increasing role of dogs, as well as a rising number of deaths from hydrophobia in humans after contact with cats $(11,23,25,30,32)$.

Rabies remains a serious endemic disease of animal populations in many European countries (4, 9, 20, 26, $29,34)$. Oral vaccination with rabies vaccines has been proven to be effective in control and elimination of terrestrial rabies for a long time $(2,3,6,7,18,27,38)$. However, the recurrence of rabies in some countries demonstrates the fragility of the status of a rabies-free country and the need for continuous surveillance. In eastern and southern countries, fox rabies control programs should be accompanied by measures to control stray dogs, given their high population in certain areas $(9,10,39)$. Inadequate rabies control among domestic animals remains an urgent problem, which can only be solved by joint efforts of veterinary service as well as experts in veterinary and human medicine. The purpose of our study was to perform a retrospective analysis of the spread of rabies among humans and animals in the Poltava and Sumy regions of Ukraine in the years 2009-2019. 


\section{Material and methods}

Data collection. The data originated from reports on rabies cases among humans and animals in central and north-eastern regions of Ukraine (Poltava and Sumy) between the years 2007 and 2020. The statistical data were obtained from the anti-epizootic division of the Department of Food Safety and Veterinary Medicine of the State Food and Consumer Service in the Poltava and Sumy regions of Ukraine.

Vaccination program. In the Poltava and Sumy regions of Ukraine, a campaign of oral vaccination of wild animals with two types of vaccines (Brovarabies V-RG and Orisvac produced by TOV Ukrvetprompostach, Brovary, Ukraine) was performed between 2006 and 2019. In the process of oral vaccination, also epizootic surveillance, serological monitoring, and teeth examination for the presence of tetracycline were carried out in all agricultural and hunting areas of the Sumy and Poltava regions.

Serological survey. For serological, surveillance, blood sera from red foxes were examined. The foxes were shot at the rate of 2-4 specimens per $100 \mathrm{~km}^{2} 30$ days after baiting, and control areas were determined to evaluate vaccine consumption on days 4,8 , and 15 after vaccine baiting. Assuming that $100 \%$ of the oral vaccine was consumed, the efficacy of preventive vaccination was analyzed. For this purpose, control shooting of foxes was carried out in these regions 30 days after baiting. Anti-rabies virus antibodies in blood sera or transudates from foxes were detected by a specific ELISA method (BioPro Rabies ELISA Ab Kit, Czech Republic), and a threshold of positivity of $0.5 \mathrm{UI} /$ $\mathrm{mL}$ was adopted.

Tetracycline test. The efficacy of the oral vaccination in foxes was assessed by a direct examination of the specific serological immune response in foxes and indirectly by verifying the uptake of vaccine baits through the detection of a tetracycline marker in foxes' teeth.

The tetracycline biomarker was detected by examining transverse sections of canine teeth $(150 \mu \mathrm{m}$ thick $)$ cut with a low speed saw (microtome Leica SP-1600, Germany). The teeth sections were stored at $-20^{\circ} \mathrm{C}$ until microscopic examination. The samples were investigated under a fluorescence microscope (Carl Zeiss, Germany) at magnification $10 \times / 0.25$ or $40 \times / 0.75$ and with a DAPI filter with an excitation wavelength of $390 \mathrm{~nm}$ and emission wavelength of $560 \mathrm{~nm}$.

The lower jaws were sampled to examine teeth for the presence of tetracycline, and blood samples were taken to be examined for the presence of virus-neutralizing antibodies.

\section{Results and discussion}

Statistical data on the dynamics of human rabies incidence in Ukraine, obtained from the Civil Service of Ukraine for Food Safety and Consumer Protection, showed that the highest incidence of rabies was recorded in 2007 ( 7 cases), followed by a gradual decrease and a subsequent peak in 2011 ( 6 cases, all of them fatal: 2 in the Vinnytsia, Donetsk, and Luhansk regions each) and another in 2015 (6 cases), i.e. 3-4 years later. It should be noted that in 2011 there were 96682

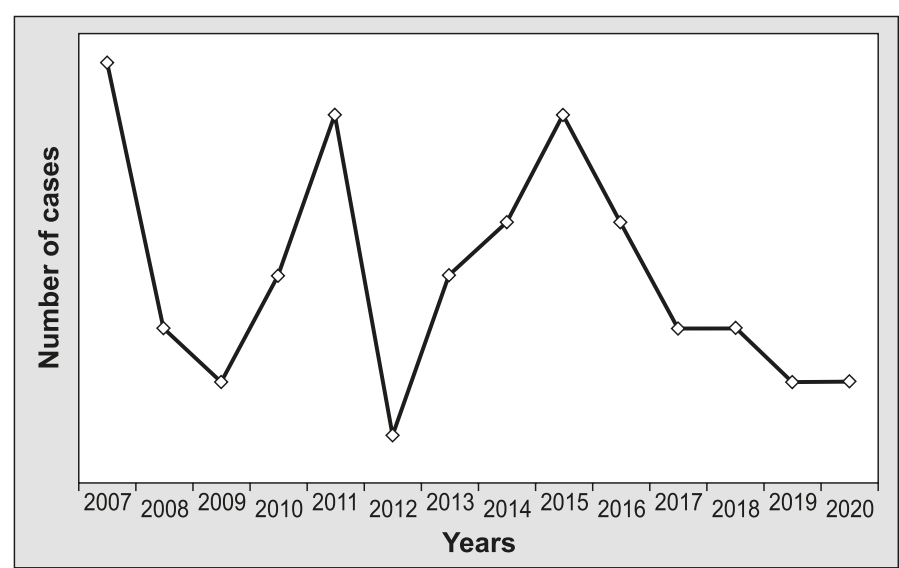

Fig. 1. Number of rabies cases among humans in Ukraine in 2007-2020

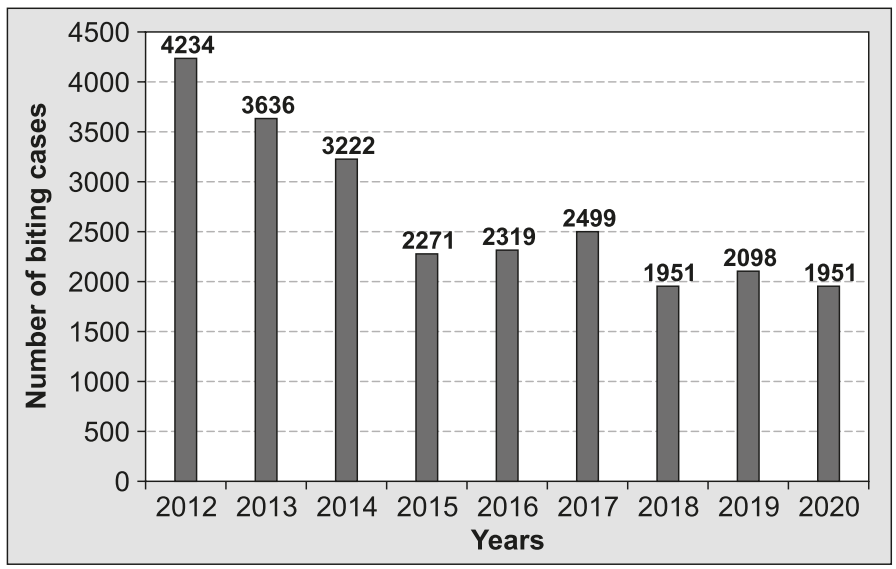

Fig. 2. Dynamics of human bite cases in the Poltava region for 2012-2020

persons in Ukraine who sought medical assistance because of animal attacks, including 2016 persons who had been attacked by animals suspected of rabies, and 3 of these cases were fatal (in the Sumy, Chernihiv and Donetsk regions). In 2015, 6 persons died of rabies: residents of the Donetsk (2 cases), Dnipropetrovsk ( 2 cases), Odessa, and Kharkiv regions, including two children under 17 years of age. In Ukraine, 1-7 persons die of this dangerous disease almost every year (32 deaths between 2008 and 2018).

In the Poltava region during 2012-2020, the highest number of human bite cases was recorded in 2012 (4234 cases) and the lowest in 2018 (1951 cases). It is worth noting that $99 \%$ of rabies cases were dogs, and among humans the most affected group were children under 15 years of age (Fig. 1).

As far as bites by dogs and cats are concerned, the largest number of humans in the Poltava region were bitten by dogs and cats that had an owner, and this number showed a gradual tendency to increase. The vast majority of rabies cases among domestic carnivores were reported in animals that had an owner, but had not received preventive rabies vaccination (Fig. 2).

The number of human bites by domestic animals in the Sumy region in 2017-2019 was almost 50\% higher than that of bites caused by vaccinated and stray animals (Fig. 3). 


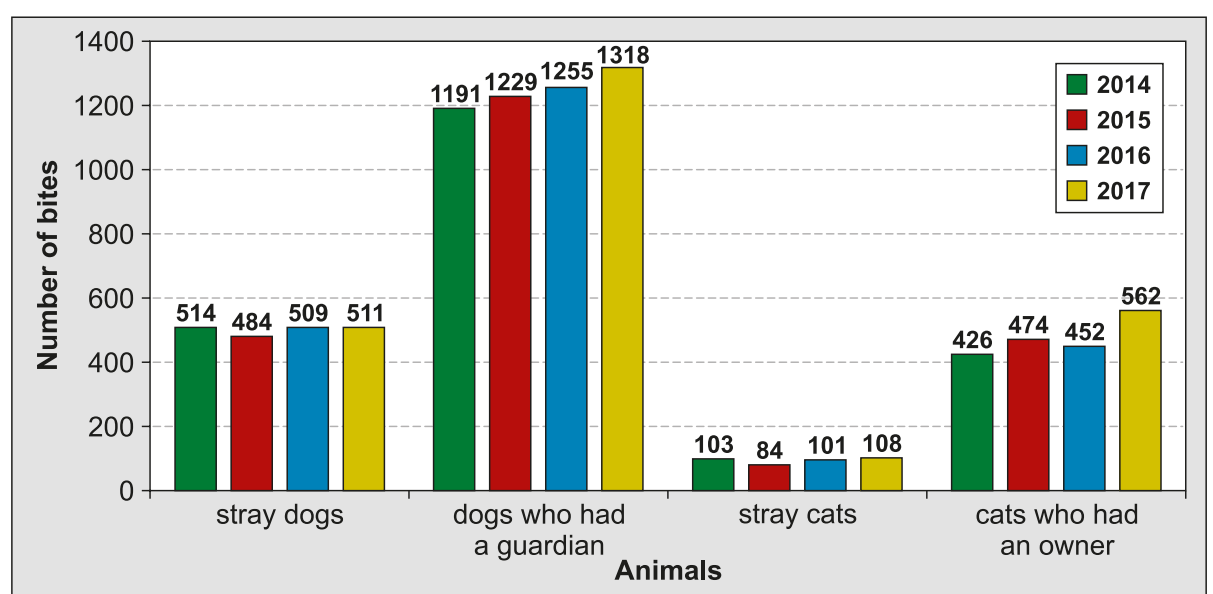

Fig. 3. Number of people bitten by animals in 2014-2017 in the Poltava region (according to the Poltava regional center of the State Sanitary and Epidemiological Service of Ukraine)

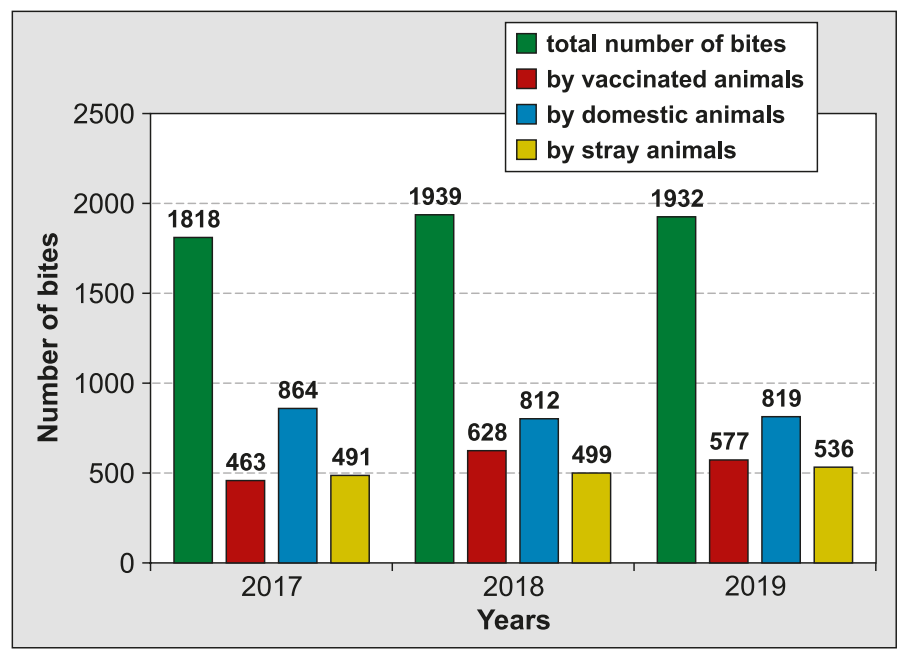

Fig. 4. Number of human bite cases in the Sumy region in 2017-2019

Statistical data on the dynamics of animal rabies in Ukraine reported by the State Food and Consumer Service in the Poltava region show that the highest prevalence of rabies was observed in 2012, with 1979 cases, and the lowest in 2018, with 891 cases (Fig. 4). It should be noted that lowest occurrence of rabies has been registered in 2009, 2012, and 2019. A total of 14,465 cases of rabies were diagnosed during this period in various animal species, and the number of rabies-affected localities was 16,560 , with an average

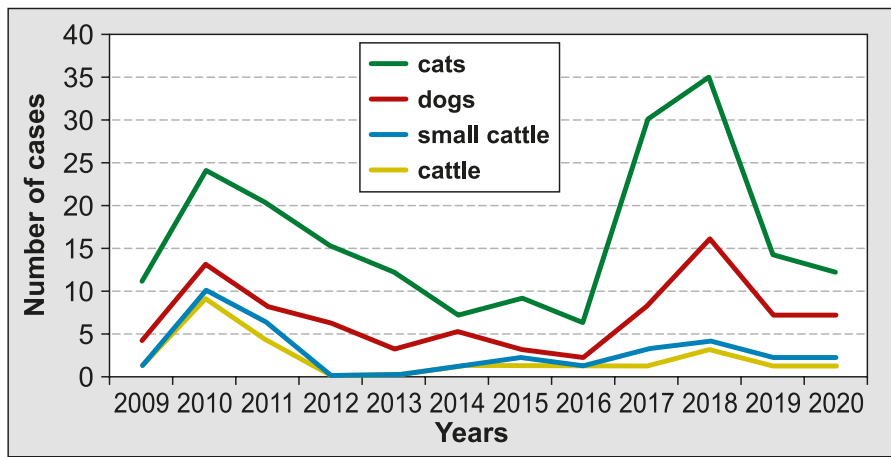

Fig. 6. Species structure of animal rabies incidence in the Poltava region in 2009-2020 of $1,554 \pm 594.73$ cases of rabies and $1,380 \pm 455.05$ recorded annually.

The prevalence of rabies in the years 2009-2020 in Ukraine was unstable, but tended to decrease in our opinion, due to the intensive vaccination of domestic animals and oral immunization of free-ranging animals (Fig. 5). In the Poltava region in 2009-2020, the incidence of rabies among wild animals was highest in foxes, whereas among agricultural and domestic animals, it was highest in cattle and cats. The largest number of diseased animals was recorded among dogs in 2018 , whereas among cattle the peak incidence occurred in 2010 (Fig. 6). In our opinion, the spread of the rabies virus in towns and villages is due to the insufficient control over stray animals and the lack of shelters. Communal temporary kennels do not solve the problem, as the animals are not revaccinated, and after 10 days of detention they are left out on the street, where they form aggressive packs.

A similar trend was observed among rabies-infected animals in the Sumy region, but the highest incidence of rabies in animals was recorded in 2010 (Fig. 7).

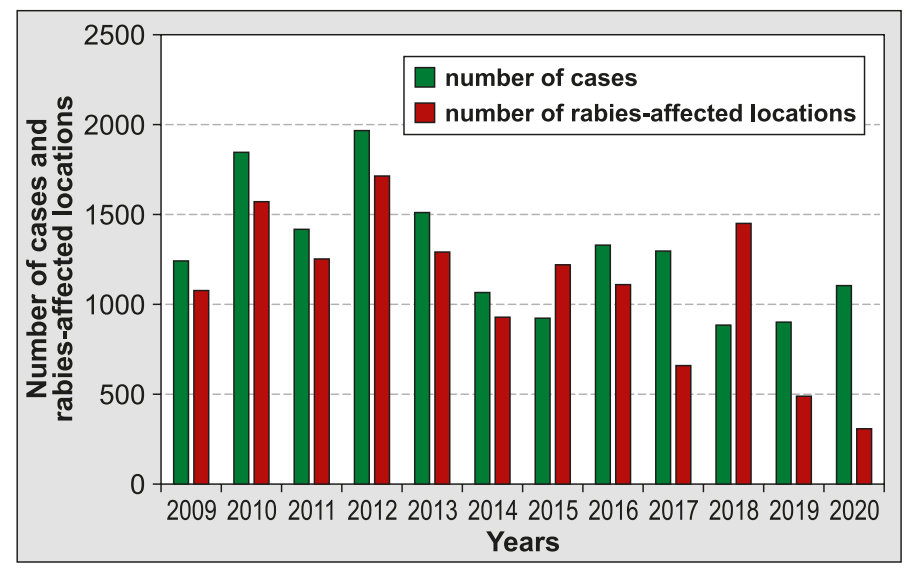

Fig. 5. Dynamics of animal rabies spread in Ukraine in 2009$-2020$

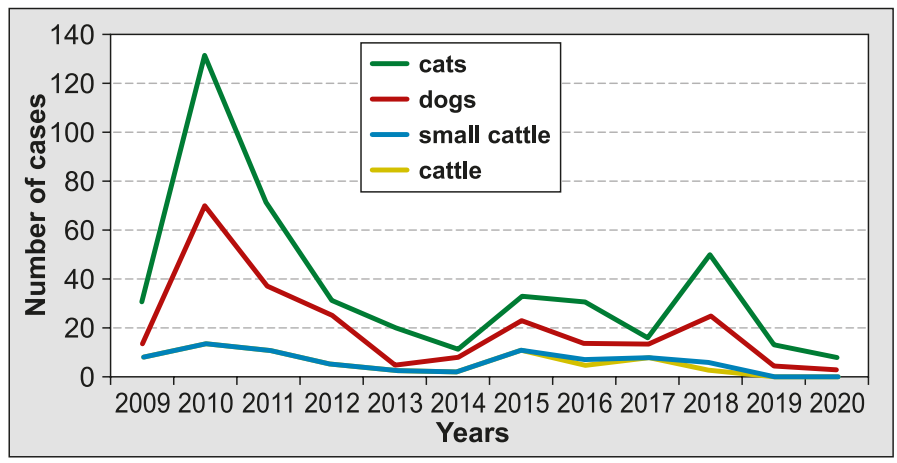

Fig. 7. Species structure of animal rabies incidence in the Sumy region in 2009-2020 


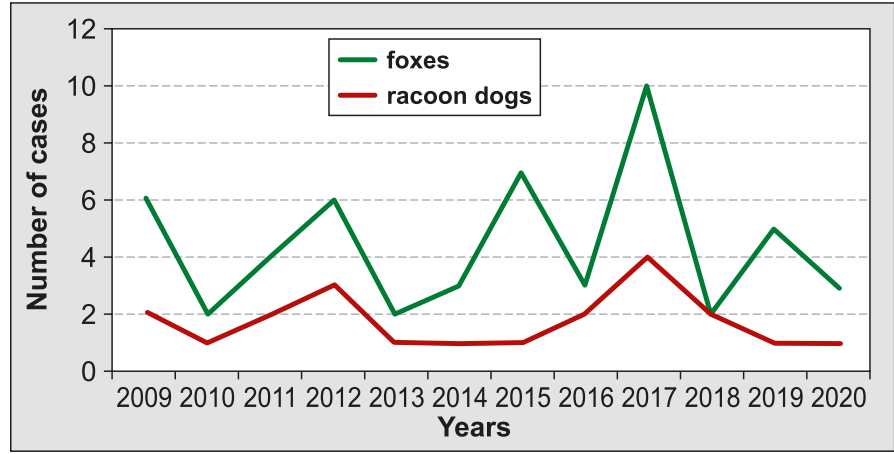

Fig. 8. Number of rabies cases among wild animals in the Poltava region in 2009-2020

The incidence of rabies among wild animals in the Poltava region (Fig. 8) was highest in 2017 (10 cases). In 2018, the number of rabies cases among wild animals decreased significantly (to 2 cases), which was associated with the beginning of oral immunization.

Unlike in the Poltava region, the peak incidence among wild animals in the Sumy region occurred in 2010 (Fig. 9).

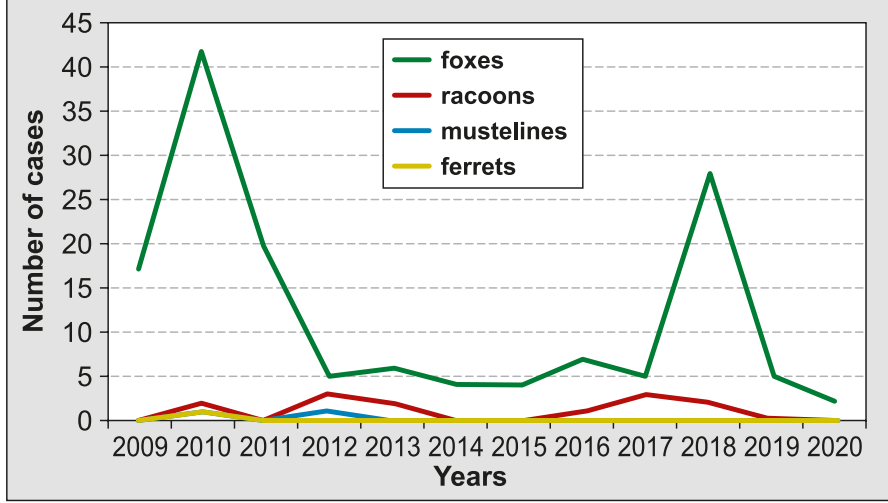

Fig. 9. Number of rabies cases among wild animals in the Sumy region in 2009-2020

Among wild animals infected with rabies, the most numerous was the red fox (Fig. 10), and the peak incidence of rabies in the Poltava region in the period of 2009-2020 occurred in 2017 (10 cases), which was associated with the end of oral immunization in 2016. In the Sumy region, the incidence among foxes peaked in 2010 and 2018 (42 and 28 cases, respectively),

Tab. 1. Oral vaccination campaigns in the Poltava region during 2006-2020

\begin{tabular}{|c|c|c|c|c|c|c|c|c|c|c|c|}
\hline \multirow{2}{*}{ 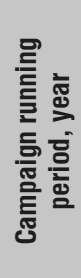 } & \multirow{2}{*}{ 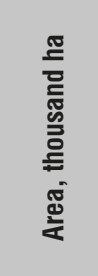 } & \multirow[b]{2}{*}{ 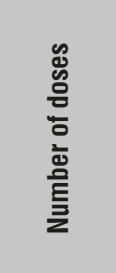 } & \multirow[b]{2}{*}{ 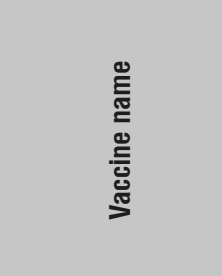 } & \multirow{2}{*}{ 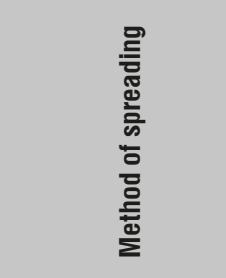 } & \multicolumn{3}{|c|}{$\begin{array}{l}\text { Collection rate of vaccine baits } \\
\text { by animals, } \%\end{array}$} & \multicolumn{2}{|c|}{$\begin{array}{l}\text { Number of } \\
\text { samples }\end{array}$} & \multicolumn{2}{|c|}{$\begin{array}{c}\text { Number of } \\
\text { positive samples }\end{array}$} \\
\hline & & & & & day 4 & day 8 & day 15 & 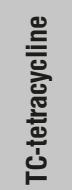 & $\begin{array}{l}\text { 잏 } \\
\text { 은 } \\
\text { 잉 }\end{array}$ & 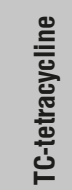 & $\begin{array}{l}\overline{\mathbb{S}} \\
\text { 음 } \\
\text { 잉 }\end{array}$ \\
\hline 2006 & 18,000 & 300,000 & $\begin{array}{l}\text { Brovarabies V-RG } \\
\text { (Ukraine) }\end{array}$ & $\begin{array}{l}\text { Terrestrial baiting } \\
\text { with vaccine }\end{array}$ & 31.8 & 57.2 & 92.7 & 90 & 65 & 54 & 28 \\
\hline 2007 & 18,000 & 320,000 & $\begin{array}{l}\text { Brovarabies V-RG } \\
\text { (Ukraine) }\end{array}$ & $\begin{array}{l}\text { Aerial baiting with } \\
\text { vaccine }\end{array}$ & 32.4 & 61.3 & 93.8 & 100 & 70 & 38 & 34 \\
\hline 2008 & 37,052 & 340,000 & $\begin{array}{l}\text { Brovarabies V-RG } \\
\text { (Ukraine) }\end{array}$ & $\begin{array}{l}\text { Aerial baiting with } \\
\text { vaccine }\end{array}$ & 36.7 & 75.8 & 93.1 & 170 & 145 & 48 & 79 \\
\hline 2009 & 18,500 & 550,000 & $\begin{array}{l}\text { Brovarabies V-RG } \\
\text { (Ukraine) }\end{array}$ & $\begin{array}{l}\text { Aerial baiting with } \\
\text { vaccine }\end{array}$ & 39.3 & 74.2 & 97.8 & 120 & 96 & 45 & 34 \\
\hline 2010 & 18,500 & 317,500 & $\begin{array}{l}\text { Brovarabies V-RG } \\
\text { (Ukraine) }\end{array}$ & $\begin{array}{l}\text { Terrestrial baiting } \\
\text { with vaccine }\end{array}$ & 40.3 & 77.4 & 94.9 & 150 & 134 & 42 & 72 \\
\hline 2011 & 19,000 & 340,000 & $\begin{array}{l}\text { Brovarabies V-RG } \\
\text { (Ukraine) }\end{array}$ & $\begin{array}{l}\text { Aerial baiting with } \\
\text { vaccine }\end{array}$ & 43.5 & 79.8 & 95.3 & 170 & 145 & 38 & 85 \\
\hline 2012 & 40,000 & 348,000 & $\begin{array}{l}\text { Brovarabies V-RG } \\
\text { (Ukraine) }\end{array}$ & $\begin{array}{l}\text { Aerial baiting with } \\
\text { vaccine }\end{array}$ & 53.1 & 82.4 & 96.2 & 280 & 220 & 48 & 96 \\
\hline 2013 & 38,000 & 540,000 & $\begin{array}{l}\text { Brovarabies V-RG } \\
\text { (Ukraine) }\end{array}$ & $\begin{array}{l}\text { Aerial baiting with } \\
\text { vaccine }\end{array}$ & 52.8 & 80.5 & 97.4 & 429 & 390 & 94 & 142 \\
\hline 2014 & 36,000 & 660,000 & $\begin{array}{l}\text { Brovarabies V-RG } \\
\text { (Ukraine) }\end{array}$ & $\begin{array}{l}\text { Terrestrial baiting } \\
\text { with vaccine }\end{array}$ & 62.3 & 92.6 & 95.9 & 440 & 375 & 64 & 128 \\
\hline 2015 & 20,676 & 330,000 & $\begin{array}{l}\text { Brovarabies V-RG } \\
\text { (Ukraine) }\end{array}$ & $\begin{array}{l}\text { Terrestrial baiting } \\
\text { with vaccine }\end{array}$ & 45.8 & 76.9 & 92.8 & 304 & 286 & 52 & 119 \\
\hline 2017 & 20,675 & 330,000 & $\begin{array}{l}\text { Brovarabies V-RG } \\
\text { (Ukraine) }\end{array}$ & $\begin{array}{l}\text { Terrestrial baiting } \\
\text { with vaccine }\end{array}$ & 46.5 & 75.7 & 92.0 & 412 & 370 & 75 & 325 \\
\hline 2018 & 23,870 & 470,750 & Orisvac (Ukraine) & $\begin{array}{l}\text { Aerial baiting with } \\
\text { vaccine }\end{array}$ & 34.9 & 67.1 & 88.4 & 510 & 465 & 442 & 414 \\
\hline 2019 & 20,700 & 518,000 & Orisvac (Ukraine) & $\begin{array}{l}\text { Aerial baiting with } \\
\text { vaccine }\end{array}$ & 37.1 & 71.6 & 87.9 & 570 & 412 & 394 & 390 \\
\hline 2020 & 20,729 & 518,230 & Orisvac (Ukraine) & $\begin{array}{l}\text { Aerial baiting with } \\
\text { vaccine }\end{array}$ & & rfo & & 707 & 630 & 524 & 585 \\
\hline
\end{tabular}

Note: in 2016 oral immunization was not performed 
Tab. 2. Oral vaccination campaigns in the Sumy region in 2006-2020

\begin{tabular}{|c|c|c|c|c|c|c|c|c|c|c|c|}
\hline \multirow{2}{*}{ 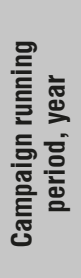 } & \multirow{2}{*}{ 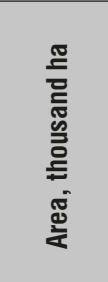 } & \multirow{2}{*}{ 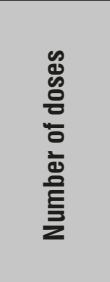 } & \multirow[b]{2}{*}{ 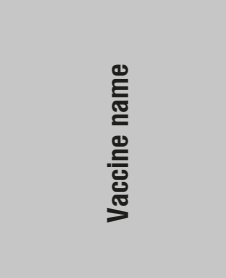 } & \multirow{2}{*}{ 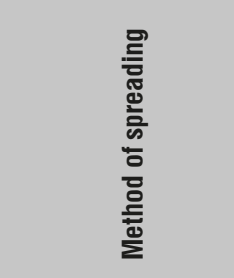 } & \multicolumn{3}{|c|}{$\begin{array}{l}\text { Collection rate of vaccine baits } \\
\text { by animals, } \%\end{array}$} & \multicolumn{2}{|c|}{ Number of samples } & \multicolumn{2}{|c|}{$\begin{array}{l}\text { Number of positive } \\
\text { samples }\end{array}$} \\
\hline & & & & & day 4 & day 8 & day 15 & 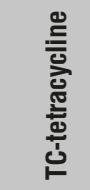 & $\begin{array}{l}\overline{ㅇ ㅡ ㅁ ~} \\
\text { 음 } \\
\text { 잉 }\end{array}$ & 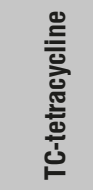 & 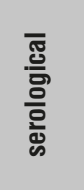 \\
\hline 2006 & 17,000 & 130,840 & $\begin{array}{l}\text { Brovarabies V-RG } \\
\text { (Ukraine) }\end{array}$ & $\begin{array}{l}\text { Terrestrial baiting } \\
\text { with vaccine }\end{array}$ & 27.5 & 58.8 & 76.5 & 78 & 65 & 18 & 26 \\
\hline 2007 & 17,000 & 280,660 & $\begin{array}{l}\text { Brovarabies V-RG } \\
\text { (Ukraine) }\end{array}$ & $\begin{array}{l}\text { Terrestrial baiting } \\
\text { with vaccine }\end{array}$ & 30.5 & 66.3 & 83.5 & 65 & 70 & 20 & 33 \\
\hline 2008 & 34,752 & 559,900 & $\begin{array}{l}\text { Brovarabies V-RG } \\
\text { (Ukraine) }\end{array}$ & $\begin{array}{l}\text { Aerial baiting with } \\
\text { vaccine }\end{array}$ & 31.4 & 66.2 & 83.5 & 153 & 99 & 52 & 38 \\
\hline 2009 & 17,325 & 580,000 & $\begin{array}{l}\text { Brovarabies V-RG } \\
\text { (Ukraine) }\end{array}$ & $\begin{array}{l}\text { Aerial baiting with } \\
\text { vaccine }\end{array}$ & 32.3 & 65.4 & 84.1 & 203 & 133 & 72 & 77 \\
\hline 2010 & 17,581 & 280,540 & $\begin{array}{l}\text { Brovarabies V-RG } \\
\text { (Ukraine) }\end{array}$ & $\begin{array}{l}\text { Terrestrial baiting } \\
\text { with vaccine }\end{array}$ & 49.9 & 75.3 & 92.0 & 108 & 54 & 35 & 21 \\
\hline 2011 & 34,795 & 530,000 & $\begin{array}{l}\text { Brovarabies V-RG } \\
\text { (Ukraine) }\end{array}$ & $\begin{array}{l}\text { Aerial baiting with } \\
\text { vaccine }\end{array}$ & 36.1 & 41.6 & 89.9 & 155 & 107 & 49 & 23 \\
\hline 2012 & 34,809 & 530,000 & $\begin{array}{l}\text { Brovarabies V-RG } \\
\text { (Ukraine) }\end{array}$ & $\begin{array}{l}\text { Aerial baiting with } \\
\text { vaccine }\end{array}$ & 38.5 & 59.2 & 84.7 & 218 & 164 & 45 & 71 \\
\hline 2013 & 34,809 & 530,000 & $\begin{array}{l}\text { Brovarabies V-RG } \\
\text { (Ukraine) }\end{array}$ & $\begin{array}{l}\text { Aerial baiting with } \\
\text { vaccine }\end{array}$ & 39.9 & 70.5 & 93.9 & 138 & 93 & 42 & 14 \\
\hline 2014 & 34,451 & 530,000 & $\begin{array}{l}\text { Brovarabies V-RG } \\
\text { (Ukraine) }\end{array}$ & $\begin{array}{l}\text { Terrestrial baiting } \\
\text { with vaccine }\end{array}$ & 45.1 & 69.4 & 91.8 & 150 & 110 & 46 & 28 \\
\hline 2018 & 17,665 & 441,642 & Orisvac (Ukraine) & $\begin{array}{l}\text { Aerial baiting with } \\
\text { vaccine }\end{array}$ & 39.0 & 70.0 & 92.0 & 564 & 434 & 429 & 411 \\
\hline 2019 & 17,674 & 883,700 & Orisvac (Ukraine) & $\begin{array}{l}\text { Aerial baiting with } \\
\text { vaccine }\end{array}$ & 43.0 & 83.0 & 93.0 & 615 & 535 & 522 & 467 \\
\hline 2020 & 17,674 & 441,850 & Orisvac (Ukraine) & $\begin{array}{l}\text { Aerial baiting with } \\
\text { vaccine }\end{array}$ & & erforn & & 230 & 158 & 123 & 55 \\
\hline
\end{tabular}

Note: in 2015-2017 oral immunization was not performed

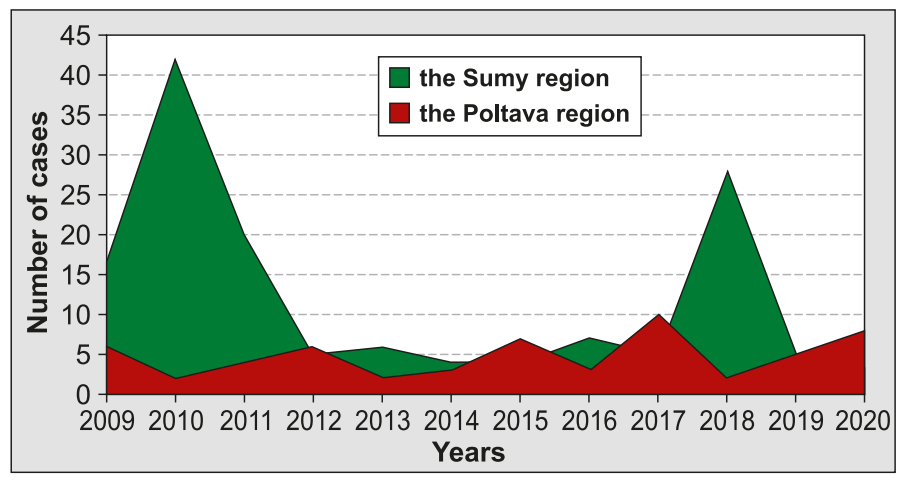

Fig. 10. Number of rabies cases among foxes in the Sumy and Poltava regions in 2009-2020

which, again, was associated with the discontinuation of oral immunization in 2015-2017. It was found that the percentage of Brovarabies V-RG (Ukraine) and Orisvac (Ukraine) vaccines collected by free-ranging animals in the Poltava region (Tab. 1-2, Fig. 11-12) tended to increase on days 4,8 , and 15 (amounting to $42.81 \pm 9.08 \%, 80.32 \pm 10.8 \%$, and $93.7 \pm 3.05 \%$, respectively). In the Poltava region, with a terrestrial distribution of vaccine baits, the Brovarabies V-RG vaccine had the best collection at the day 4 after administration. Thus, in 2014, this percentage was $62.3 \%$. This was more than the best result obtained with aerial vaccine baiting, which was $52.8 \%$ in 2013 . In contrast, the Orisvac vaccine (Ukraine) proved to be effective in aerial vaccine baiting, with high percentages of positive biological material samples. In 2018 and 2019 , this percentage reached $89.03 \%$ and $94.6 \%$ of positive serological samples, respectively (Fig. 11). At the same time, the positive results from the studies on TC-tetracycline and serological assays showed high values $(110.31 \pm 113.43$ and $149.69 \pm 116.09$, respectively).

In case of terrestrial vaccine baiting during the campaign of oral vaccination with Brovarabies V-RG (Ukraine) in the Sumy region in 2006-2020, collection rate was the highest in 2010 and 2014 (49.9\% and $45.1 \%$, respectively). In case of aerial vaccine baiting in that region in 2013 and 2019, the collection rate was lower (39.9\% and 43.0\%, respectively) (Tab. 2).

It should be noted that the percentage of Brovarabies V-RG (Ukraine) and Orisvac (Ukraine) vaccines collection rate in the Sumy region, unlike in the Poltava region, showed significant fluctuations on days 4,8 , and 15 , respectively. 


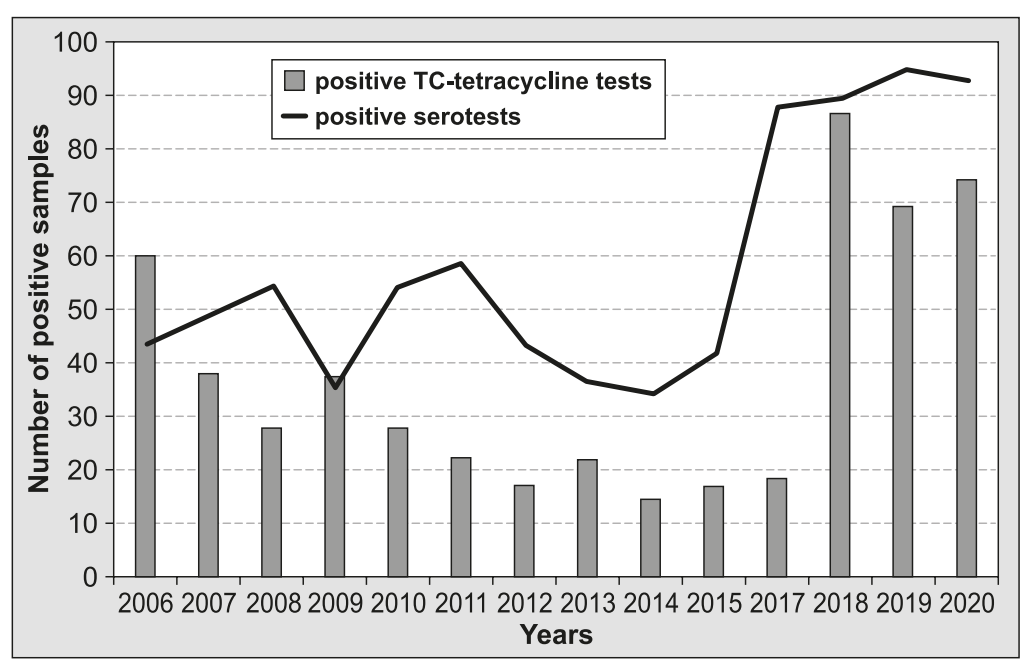

Fig. 11. Results of tests on pathological (biological) material obtained from foxes in the Poltava region in 2006-2020

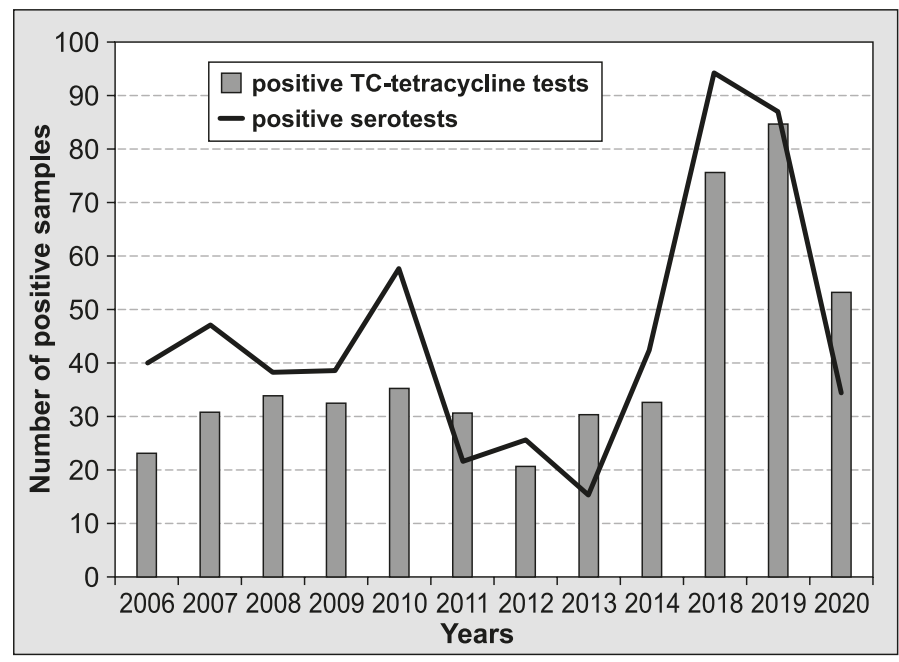

Fig. 12. Results of tests of pathological (biological) material obtained from foxes in the Sumy region in 2006-2020

In contrast, the Orisvac vaccine (Ukraine) proved to be effective in aerial vaccine baiting, as demonstrated by high percentages of positive samples of biological material. Thus, in 2018 and 2019, this percentage reached $87.2 \%$ and $94.7 \%$ of positive serological tests, respectively (Fig. 12). We can conclude that the use of Brovarabies V-RG (Ukraine) was most effective with the terrestrial method of baiting in 2010 and 2014, whereas Orisvac (Ukraine) gave best results in aerial vaccine baiting (in 2018 and 2019). The positive results of both TC-tetracycline and serological tests reached high values $(120.90 \pm 177.16$ and $109.9 \pm 164.39$, respectively) (Fig. 12).

Our studies in 2019 revealed that $84.8-86.6 \%$ of the fox population in the Sumy and Poltava regions consumed Orisvac vaccine (according to the results of the tetracycline test), and $87.2-94.6 \%$ of the animals had virus-neutralizing antibodies to rabies (at the rate of $75 \%$ and above), which is sufficient to create an immunological barrier in wild carnivores.

Rabies is a particularly dangerous zoonotic infection of great social and economic importance. Prevention of rabies and immune protection of humans and animals are therefore particularly important. The number of people bitten in the Poltava region during 2012-2020 was largest in 2012 (4234 cases) and smallest in 2018 (1951 cases). Most people were bitten by dogs and cats who had an owner, and the number of such incidents had a tendency to grow. In 2017-2019, the number of people bitten by domestic animals in the Sumy region was almost 50\% higher than the number of those bitten by vaccinated and stray animals. In our opinion, rabies activity among animals during 2009-2020 was restricted, in line with intensive vaccination of domestic animals and oral immunization of wild animals. The incidence of rabies in the Poltava region in 2009-2020 was highest in foxes, as far as wild animals are concerned, as well as in cattle and cats, when it comes to domestic animals. Analyzing the species structure of rabies-infected animals in the Poltava region in 2009-2020, it was found that the largest number of diseased animals was recorded among dogs in 2018, and the peak among cattle was observed in 2010. We found similar tendencies among rabies-infected animals in the Sumy region, with the highest incidence of animal rabies reported in 2010. The red fox was the most numerous among infected wild animals, and again the peak incidence of rabies in the Poltava region for the period of 2009-2020 occurred in 2017 (10 cases), and among foxes in the Sumy region the highest incidence was recorded in 2010 (42 cases). The use of Brovarabies V-RG (Ukraine) proved to be most effective in the terrestrial method of baiting in 2010 and 2014, whereas the Orisvac vaccine (Ukraine) produced best results in aerial vaccine baiting (2018 and 2019). In 2019, 84.8-86.6\% of the fox population in the Sumy and Poltava regions consumed the Orisvac vaccine (Ukraine) (according to the results of the tetracycline test), and $87.2-94.6 \%$ of the animals examined had virus-neutralizing antibodies to the rabies (at the rate of $75 \%$ and above), which is sufficient to create an immunological barrier in wild carnivores.

According to an analysis of literature sources, there have been no previous retrospective studies of rabies in farm animals for the period of 1996-2020 in the Sumy and Poltava regions of Ukraine. Our data on the species morbidity of animals with rabies are confirmed by data from Titarenko (37), where the most numerous among all animal species were cats. The many publications by foreign scientists and researchers on oral immunization against rabies became the basis for studies on the blood serum and jaws of foxes from the Sumy and Poltava regions of Ukraine. First, the efficacy of oral rabies vaccination in Ukraine depending on the type of vaccine and its application was considered. As the experience of rabies-free European countries shows, the rabies-free status can be achieved through regular vaccination over 5-10 years using the aerial baiting 
system. In our opinion, the reduction of cases in wild fauna was due to well-planned, systematic oral vaccination of animals. It is possible to eradicate rabies in the Poltava and Sumy regions by a wide implementation of oral vaccination in foxes, stray dogs and cats, and farm animals in affected holdings representing an epizootic foci. Rabies control among domestic animals remains an urgent problem, which can only be solved by the joint efforts of veterinary service, experts in veterinary and humane medicine.

In the Poltava and Sumy regions of Ukraine, rabies control programs in foxes should be accompanied by measures to combat stray dogs, given their large populations in certain areas. Breaking the chain between animals and humans, oral immunization of wild carnivores in natural reservoirs, reducing the number of stray animals, and increasing the coverage of domestic animals with rabies vaccination are priority objectives for the national medical and veterinary service.

\section{References}

1. Achilov V. G., Nedosjekov $V$. V.: Harakterystyka epizootychnogo procesu skazu v Hmel'nyc'kij oblasti. Veterynarna medytsyna Ukr. 2013, 6, 14-17.

2. Brochier B. M, Languet B., Blancou J., Kieny M. P., Lecoca J. P., Costy F. Desmettre P., Pastoret P.-P.: Use of recombinant vaccinia-rabies virus for oral vaccination of fox cubs (Vulpes vulpes, L) against rabies. Vet. Microbiol. 1988 18, 103-108.

3. Bruyere V., Vuillaume P., Cliquet F., Aubert M.: Oral rabies vaccination of foxes with one or two delayed distributions of SAG2 baits during the spring. Vet. Res. 2000, 31, 339-345.

4. Cliauet F., Robardet E., Must K., Laine M., Peik K., Picard-Meyer E., Guiot A.-L., Niin E.: Eliminating Rabies in Estonia. PLoS Negl. Trop. Dis. 2012, 6, 15-35.

5. Danilchenko A., Nedosekov V: Epizootic situation on animal rabies in the Northern and Western regions of Ukraine. Anim. Biol. 2018, 20, 16-19.

6. Dowdle W. R., Cochi S. L.: The principles and feasibility of disease eradication. Vaccine 2011, 29, 70-73.

7.Duintjer Tebbens R. J., Pallansch M. A., Cochi S. L., Wassilak S. G. F., Linkins J., Sutter R. W., Aylward R. B., Thompson K. M.: Economic analysis of the global polio eradication initiative. Vaccine 2010, 29, 334-343.

8. Golik M., Polupan I., Nedosekov V.: Forecasting of epizootic of rabies in the Chernihiv oblast on the basis of geoinformation analysis. Nauk dopovidi Nacional'nogo universitetu bioresursiv i Prir Ukraïni 2018, 5-18.

9. Johnson N., Freuling C., Horton D., Müller T., Fooks A. R.: Imported Rabies, European Union and Switzerland, 2001-2010. Emerg. Infect. Dis. 2011, 17,753-754

10.Johnson N., Un H., Fooks A. R., Freuling C., Müller T., Aylan O., Vos A.: Rabies epidemiology and control in Turkey: past and present. Epidemiol. Infect. 2010, 138, 305-312.

11. Kolosov A. E., Romanov A. V., Vialitsyn A. G.: Otsenka opasnosti zarazheniya beshenstvom v severnykh regionakh Rossii. Mezhdunarodnyy nauchnoissledovatelskiy zhurnal 2017, 59, 141-145.

12. Kopcha V. S., Burak N.: Skaz lyudini: peripetiyi specifichnoyi profilaktiki. Infekc. hvorobi. 2013, 1, 54-81.

13. Kornienko L. E., Moroz O. A., Mezhensky A. O., Skorokhod S. V., Datsenko R. A., Karpulenko M. S., Polupan I. M., Dzyuba Y. M., Nedosekov V. V., Makovskaya I. F., Hibaliuk Y. O., Sonko M. P., Tsarenko T. M., Pishchanskyi $O$. $V$ : Epizootological and epidemiological aspects for rabies in Ukraine for the period from 1999 to 2018 . Vet. Sci. Technol. Anim. Husb. Nat. Manag. 2019, 90-109.

14. Levkivsky D. M., Levkivska N. D., Storchak Yu., Gutyj B. V.: Epizootological monitoring of animal rabies in the Lviv region for 2014-2016, the analysis of rabies events. Sci. Messenger LNU Vet. Med. Biotechnol. 2016, 18, 50-53.

15. Makovska I. F., Nedosekov V. V., Kornienko L. Y., Novokhatny Y. O., Nebogatkin I. V., Yustyniuk V. Y.: Retrospective study of rabies epidemiology in Ukraine (1950-2019). Theor. Appl. Vet. Med. 2020, 8, 36-49.

16. Makovska I. F., Nedosekov V. V., Polupan I. M., Latmanizova T. S.: Distribution trend rabies in cats in Ukraine. Sci. Messenger LNU Vet. Med. Biotechnol. 2018, 20, 18-23.
17. Mazur M., Mazur N., Polupan I.: Characteristics of epizootic situation of rabies for the animal species in Ukraine from 2011-2016. Sci. Messenger LNU Vet. Med. Biotechnol. 2017, 19, 159-162.

18. Movsesyants A. A., Olefir Y. V.: Current Challenges of Preventive Vaccination Against Rabies. Bioprep. Prev. Diagnosis, Treat 2019, 19, 10-16.

19. Naglov V., Oboskalova D.: Osoblyvosti skazu tvaryn u mistah Harkivs'koi' oblasti. Nauk visnyk Uzhgorods'kogo universytetu, Ser. «Biologija» 2005, 17, 67-79.

20. Niin E., Laine M., Guiot A. L., Demerson J. M., Cliquet F.: Rabies in Estonia: Situation before and after the first campaigns of oral vaccination of wildlife with SAG2 vaccine bait. Vaccine 2008, 26, 355-356.

21. Nikiforov V. V., Avdeeva M. G.: Rabies. Actual issues. Epidemiol. Infect. Dis. (Russian Journal) 2017, 22, 295-305.

22. Nikiforov $V$. V, Malov $V$. A., Trusova $N$. V.: The problems of clinical and epidemiological basis of diagnosis of rabies in the example of case history observation. Epidemiol. Infect. Dis. 2016, 21, 211-218.

23. Nuratinov R. A.: Kratkaya harakteristika nozoareala beshenstva. Yug. Ross. Ekol. Razvit. 2011, 6, 176-180.

24. Oleksenko $O$. V.: Historical retrospective and prospect of rabies infection in Ukraine. Infectious Diseases 2020, 4, 48-52.

25. Onishchenko G. G., Popova A. Y., Ezhlova E. B., Demina Y. V., Pakskina N. D. Pistsov M. N., Rubtsov V. V., Suroryatkin A. V., Petrov A. A., Kazantsev A. V., Berezhnoy A. M., Zverev A. Y., Manoshkin A. V.: Epidemiological situation on and problems of identification of rabies virus in humans in the territory of the Russian Federation during the period of 2002-2015. Probl. Part Danger Infect. 2017, 27-32.

26. Pastoret P. P., Brochier B.: Epidemiology and control of fox rabies in Europe. Vaccine 1999, 17, 1750-1754.

27. Pirio G. A., Kaufmann J.: Polio Eradication Is Just Over the Horizon: The Challenges of Global Resource Mobilization. J. Health. Commun. 2010, 15, 68-63.

28. Savenko M. M.: Epizootic peculiarities of the rage of animals in the Kirovograd region. Probl. zoinengineering Vet. Med. Collect. Sci. Work Vet. Sci. 2015, 30, 190-193.

29. Selhorst T., Müller T., Schwermer H., Ziller M., Schlüter H., Breitenmoser U. Müller U., Brochier B., Pastoret P.-P., Mutinelli F.: Use of an Area Index to Retrospectively Analyze the Elimination of Fox Rabies in European Countries. Environ. Manage. 2005, 35, 292-302.

30. Shabejkin A. A., Guljukin A. M., Caregradskij P. J., Parshikova A. V., Juzhakov A. G., Zajkova O. N.: Analiz tekushey epizooticheskoy situatsii po beshenstvu na territorii Rossiyscoy Federacii. Ross. Vet. zhurnal 2015, 6, 6-8.

31. Shlim D. R.: Preventing rabies: the new WHO recommendations and their impact on travel medicine practice. J. Travel. Med. 2018, 1, 1-2.

32. Simonova E. G., Saburova S. A., Levina K. Y., Shabeykin A. A., Raichich S. R. Ladnyi $V$. I.: Sovremennaya situaciya i osnovnye napravleniya borby i profilaktiki beshenstva v Rossijskoj Federacii. Lechashij vrach 2019, 6, 74-76.

33. Steck F., Wandeler A., Bichsel P., Capt S., Schneider L.: Oral Immunisation of Foxes against Rabies: A Field Study. Zentralblatt für Veterinärmedizin R B 2010, 29, 372-396

34. Stöhr K., Meslin F.-M.: Progress and setbacks in the oral immunisation of foxes against rabies in Europe. Vet. Rec. 1996, 139, 32-35.

35. The European Union summary report on trends and sources of zoonoses, zoonotic agents and food-borne outbreaks in 2014. EFSA J 2015, 13, 4329.

36. Tischendorf L., Thulke H.-H., Staubach C., Müller M. S., Jeltsch F., Goretzki J., Selhorst T., Müller T., Schluter H., Wissel C.: Chance and risk of controlling rabies in large-scale and long-term immunized fox populations. Proc. R. Soc. London Ser. B Biol. Sci. 1998, 265, 839-846.

37. Titarenko E. $V$ : Analisis of the epizootic situation on animals rabies in Poltava region. Vet. Sci. Technol. Anim. Husb. Nat. Manag. 2019, 4-10.

38. Townsend S. E., Lembo T., Cleaveland S., Meslin F. X., Miranda M. E., Putra A. A. G., Haydon D. T., Hampson K.: Surveillance guidelines for disease elimination: A case study of canine rabies. Comp. Immunol. Microbiol. Infect. Dis. 2013, 36, 249-261.

39. Vigilato M. A. N., Cosivi O., Knöbl T., Clayijo A., Silva H. M. T.: Rabies Update for Latin America and the Caribbean. Emerg. Infect. Dis. 2013, 19, 678-679.

40. Wandeler A. I., Capt S., Kappeler A., Hauser R.: Oral Immunization of Wildlife Against Rabies: Concept and First Field Experiments. Clin. Infect. Dis. 1988, 10, 649-653.

41. Wendt A., Kreienbrock L., Campe A.: Zoonotic Disease Surveillance Inventory of Systems Integrating Human and Animal Disease Information. Zoonoses Public Health 2014, 62, 61-74.

42. WHO Rabies. Information Bulletin 2016, 99, 1-2.

Corresponding author: dr Hanna Omelchenko, Poltava State Agrarian Academy, 1/3, Skovoroda Str., Poltava, Ukraine; e-mail: anna72milanko@ gmail.com 